"The EUrASEANs: journal on global socio-economic dynamics"

Volume 3 (10); May-June, Year 2018;

ISSN 2539 - 5645 (Print)

Copyright (C) 2018, [The EUrASEANs]

on-line access: https://www.euraseans.com/3(10)

\title{
FACTORS AFFECTING LOCAL AUTHORITIES' WASTE MANAGEMENT (THE CASE OF KATUMBAN DISTRICT, SAMUTSAKORN PROVINCE, THAILAND)
}

\author{
Niyom Suwandej
}

Suan Sunandha Rajabhat University, Bangkok, Thailand

The purpose of this article is to study the factors that affect the participation in management of community waste. Studying the factors affecting community participation in waste management might become a way to find how to manage wastes in the community of the Khaerai Sub-district, Katumban District, Samutsakorn Province of Thailand. This research is designed as a mixed research, that is, both qualitative and quantitative. The tools used to collect quantitative and qualitative data were as follows: 1) The tool used in quantitative collection is a questionnaire divided into 4 sections as follows. Part 1: Analysis of public data on the Khaerai Sub-district Administration Organization. Part 2: Analysis of knowledge on waste management in the community of Khaerai Sub-district. Part 3: Analysis of the factors affecting people's participation in waste management in the sub-district in question. Part 4: Analysis of household solid waste management in Khaerai Sub-district. 2) Tools used for collection of qualitative data included observations and in-depth interviews on the issues related to community's involvement in waste management.

Our research results demonstrate that most of the people in the sub-district in question are involved in reducing the volume of household waste. They always participate in separation of waste types before disposing them. The study on the solid waste management system of Khaerai Sub-district Administration Organization found that the Administration applies comprehensive community waste management, integrated with waste management. To manage the garbage at its source, dividing the garbage into four categories is used (thus, there are four cans). This helps collecting solid waste more efficiently and thus reduce the contamination of that waste that potentially can be reused. The focus should be maintained on waste sorting and also on organization of the related projects and activities. Additional measures may include providing a new waste facility for future solid waste and also promoting more ways to get rid of waste at its source. Using the participatory principles in waste management gives people more freedom in options' selection, and this, in its turn, may boost the efficiency of waste collection and waste management overall.

Keywords: participation; waste management; Khaerai sub-district.

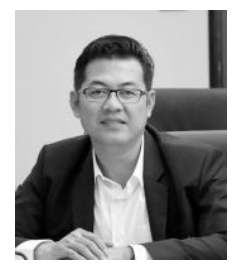

\section{Niyom Suwandej}

Doctor of Philosophy (Innovation Management),

Rajabhat Suan Sunandha University, Bangkok, Thailand

Lecturer: College of Innovation and Management, Suan Sunandha Rajaphat University,

Bangkok, Thailand

Interests : Management, Business

Email: niyom.su@ssru.ac.th, niyom.suwandej@gmail.com 


\section{Introduction}

Nowadays all problems related to waste are only intensifying due to the ongoing growth of population and higher standards of living (thus, higher levels of consumption). Continuously developing countries do their best to use the newest technologies so that to increase their productivity level. This leads to even more waste, therefore, waste management becomes as important as the pollution problem itself. Therefore, urgency in solving the problems related to waste vary from country to country, depending on population number and the rate of national economy expansion. However, the general scale of this problem is only increasing with every new year, thus both central and local administrative authorities are becoming more and more responsible for solving all related issues. Still, management of these issues has very limited capacities, mostly due to lack of professional officers and also due to lack of control. Since quite often there is also a legal gap when it comes to waste management, it is obviously difficult to operate these tasks due to lack of any norms.

Waste tends to increase in volume literary everyday, thus causing much concern. In so many cases convenience in consumption is the core of the waste problem, since the amounts of thrown away consumption products are enormous. In many situations still useful materials are being mixed with wastes, thus, it is difficult to find a suitable method to separate them. This problems is especially relevant for plastic and aluminium parts of bags, cans, boxes etc. There are currently many options at table, all aimed to eliminate (or at least reduce) waste but each of them has its limitations. Some of these options actually cause additional environmental problems related to pollution of water and air or to the extensive use of land resources. Thus, the only way to truly reduce the volume of waste in quantity is to reduce the volume of waste as such by means of making people be more aware of this problem and participate more actively in waste separation (Narong Lao-a-Longkorn, 2547, p. 1).

The human tries to escape the waste all the time, and on the other hand - the human is responsible for making it. Moreover, in the majority of cases when a new method was introduced for waste elimination, it proved to be very much unsuccessful due to lack of population participation and also because management in each separate area saw it differently in term of activities to be taken and general policy overall. In many cases such operations were simply not taken seriously and continuously enough due to lack of consciousness. Therefore, throwing waste quickly became the environmental problem of the municipal level in the first place. For many years waste management was performed very plainly - simply by taking all waste to the waste disposal places, even when part of that waste still had the value and the potential to be reused and/or recycled. For example, some parts of the waste can be processed into fertilizers. However, in many cases and countries this is not happening due to lack of knowledge on how to do it and also due to lack of population awareness (Department of Environmental Quality, 2548, p. 38).

Currently, the waste problem has globally reached the size and the limit at which it cannot be fully eliminated all and it will only continue increasing, it cannot go away as it came. Moreover, many types of waste cannot be kept at disposals due to sanitation issues under warm temperatures. However, local administration that are responsible for solving this issue, are usually very much limited in their legal and functional capacities, and also in budgeting. Besides that, population itself is often not really willing to participate in solving this issue. 


\section{FACTORS AFFECTING LOCAL AUTHORITIES WASTE}

Waste management is a system, thus, its efficiency must be managed systemically. If there are options to reduce waste or reuse it - this should be done, even under limited budget.

Direct participation of population in waste disposal initiatives of local administration is also very important. If local administration is the only waste manager, they cannot operate efficiently enough. The "fresh" waste that is not separated by types, causes the foul smell along with other pollution problems. All of these problems will affect the people around, who eventually will suffer from the community waste and their own waste. Thus, they should participate in waste management themselves as they are the key source of that waste. However, the absolute majority of Thai people still lack motivation to be directly included in waste management. Therefore, it would be interesting to get to know what are those factors affecting the people who have this experience of participation in waste management.

All of these problems described above have made the researcher consider waste management in more details, namely, the issue of people's participation in it. The important objectives for local administrations, in our view, must include the following:

providing more knowledge on waste separation,

stimulating awareness and immediate participation in waste management so that to reduce the overall volume of waste, at least on the local level.

The researcher thus intends to study the factors affecting community participation in waste management on the example of the Khaerai Sub-district, Katumban District, Samutsakorn Provice. Determination of these factor may help formulating the guidelines for further development of waste management so that the latter may reach higher efficiency and become more useful for local community. Khaerai sub-district, in the future, may also serve as an example for other local administrations in Thailand.

Thus, the objectives of this study are as follows: to analyze the factors affecting the participation of people in waste management on the example of the community in Khaerai Sub-district, Katumban District, Samutsakorn Province, Thailand.

\section{Methodology}

\section{Instrument for data collection:}

Since we intended to collect both qualitative and quantitative data, the instrument used for data collection was divided as follows:

1. The instrument used for quantitative data was a questionnaire.

The questionnaire was divided into 4 sections as follows:

Section I - Common demographic data on the people surveyed in Khaerai;

Section II - Specific data on the knowledge and understanding of waste management in Khaerai sub-district;

Section III - Data on the factors affecting people's participation in waste management in the sub-district in question;

Section IV - Data on waste management practices of the households in Khaerai.

Instrument for qualitative data collection:

Observations and in-depth interviews on the issues related to participation in waste management demonstrated by the people in the researched community. 


\section{Results}

Table 1 presents the standard demographic data on our sample from the Khaerai Subdistrict, Katumban District, Samutsakorn Province. The parameters mentioned include: gender, age, marital status, education level, career, monthly average income, community status and the number of people in a household.

Table 1. Personal data of the surveyed population

(collected and calculated by the coauthors)

\begin{tabular}{|c|c|c|}
\hline General Data & $\begin{array}{c}\text { Amount } \\
n=400\end{array}$ & $\begin{array}{c}\text { Percentage, } \\
\%\end{array}$ \\
\hline \multicolumn{3}{|l|}{ 1. Gender } \\
\hline Male & 167 & 41.75 \\
\hline Female & 233 & 58.25 \\
\hline \multicolumn{3}{|l|}{ 2. Age } \\
\hline Younger than 19 years & 11 & 2.75 \\
\hline $20-29$ years & 35 & 8.75 \\
\hline $30-39$ years & 68 & 17.00 \\
\hline $40-49$ years & 75 & 18.75 \\
\hline $50-59$ years & 133 & 33.25 \\
\hline Over 60 years & 78 & 19.50 \\
\hline \multicolumn{3}{|l|}{ 3. Marital Status } \\
\hline Single & 42 & 10.50 \\
\hline Married & 324 & 81.00 \\
\hline Living together but not married & 14 & 3.50 \\
\hline Widow & 11 & 2.75 \\
\hline Divorced/ Separated & 9 & 2.25 \\
\hline \multicolumn{3}{|l|}{ 4. Education Level } \\
\hline Primary & 215 & 53.75 \\
\hline Junior High school & 61 & 15.25 \\
\hline High School/ Vocational Certificate & 58 & 14.50 \\
\hline Technical Certificate/ Diploma & 23 & 5.75 \\
\hline Bachelor's Degree & 32 & 8.00 \\
\hline Higher than Bachelor's Degree & 11 & 2.75 \\
\hline \multicolumn{3}{|l|}{ 5. Career } \\
\hline Agriculture/Farmer & 157 & 39.25 \\
\hline Contractor & 104 & 26.00 \\
\hline Government officer / State enterprise & 25 & 6.25 \\
\hline Factory worker / Private Company & 47 & 11.75 \\
\hline Trade / Personal business & 44 & 11.00 \\
\hline Housework / housekeeper & 23 & 5.75 \\
\hline \multicolumn{3}{|l|}{ 6. Average income per month } \\
\hline lower than 5,000 Baht & 46 & 11.50 \\
\hline $5,001-10,000 \mathrm{Baht}$ & 65 & 16.25 \\
\hline $10,001-15,000$ Baht & 175 & 43.75 \\
\hline $15,001-20,000$ Baht & 34 & 8.50 \\
\hline $20,001-25,000$ Baht & 26 & 6.50 \\
\hline Over 25,000 Baht & 54 & 13.50 \\
\hline
\end{tabular}

Our analysis of the data collected from these 400 people found that most of them have somehow participated in the reduction of waste: 388 people/households confirmed this, that 


\section{FACTORS AFFECTING LOCAL AUTHORITIES WASTE}

is, $97 \%$ of the sample. And only as little as 12 people had never participated in such activities, that is, $3.0 \%$ of our sample. Quite many people stated they separate waste before throwing it away all the time - 367 people, or $91.8 \%$, while only 33 people have never done that $(8.2 \%)$.

Most of the surveyed send waste to the Sub-district Administration - 380 people, or $95.0 \%$. Only 8 people $(2.0 \%)$ from the sample burn their waste.

More details on the results, including average and standard deviation, including that on waste disposal methods used by the community in question are demonstrated in Table 2.

Table 2. Average and standard deviation for the waste management methods used in the community,

(calculated by the coauthors)

\begin{tabular}{|l|c|c|c|}
\hline \multirow{2}{*}{ Households' waste disposal methods } & \multicolumn{3}{|c|}{ Practical Level } \\
\cline { 2 - 4 } & $\bar{x}$ & S.D. & Result \\
\hline 1. Separated garbage but not before disposing & 3.94 & .837 & High \\
\hline 2. Put all garbade together in the same bag & 2.95 & 1.005 & Middle \\
\hline $\begin{array}{l}\text { 3. Separate garbage bags by each type before } \\
\text { disposing }\end{array}$ & 3.05 & 1.024 & Middle \\
\hline Total & 3.32 & .961 & Middle \\
\hline
\end{tabular}

\section{Participation in solving the problem}

\section{Reducing waste volume through direct participation}

Encouraging the reduction of waste is a direct burden on management, of course. However, the following measures at the administration level are found to be particularly useful: life;

Setting the standard for selecting the products that are more durable and/or have long

Reducing the volume of unnecessary waste components such as paper or plastic wrap, in shops, in particular;

Promoting the use of recycled materials from glass bottles, metal, paper and plastic so that to save costs and save resources at the same time;

Using recycled packing for products;

Collection of pollutants manually.

\section{Co-thinking/ Planning}

The option of direct participation in planning of waste management assumes that the community should open channels for people to participate in analyzing the problems of waste management so that the citizens really understand the importance of waste separation. Direct participation also assumes participation in preparation of waste management plans, in encouraging people to participate in waste management, in PR campaigns on waste management cooperation etc. 


\section{Cooperation}

Some of the surveyed people have been involved in the establishment of the so-called garbage banks, place or community waste trading points. There is obvious cooperation in waste management at the stage of disposing. Also, the local community uses own promotion means to popularize waste reuse and also to popularize the practice of waste separation before disposal. Some of the surveyed confirmed they were invited and/or participated in the related meetings, trainings or other public relation events related to waste management. Success of current operations tends to make population be more interested, thus, more people are coming to join the waste management projects.

\section{Cooperation monitoring and evaluation}

The waste management performance report issued in/for a community is supposed to have a certain planning schedule so that to monitor how this community is performing, whether it improves its operations, how able it is in terms of reducing the amount of waste, who exactly is participating in discussing and solving the problems of waste management. For example, a committee can be assigned to monitor and evaluate waste management operations. This committee could not only evaluate all related processes but also what can be future operations in the context of waste management reform.

\section{Conclusions and Discussion}

From our research result on the factors affecting people's participation in waste management in the selected Thai community we have found that the key factors of influence upon waste management are knowledge and understanding the serious of garbage issues. The results of our interviews' analysis demonstrated that many interviewees had sufficient knowledge and understanding at a rather high level. Many of those were already actively using the recommended waste management guidelines.

However, our result of the interviews' analysis has also found that the average knowledge of waste management guidelines as such is on the middle level in the community in question. Not many of our respondents have sufficient waste- separating skills, even when their knowledge and awareness are already at a quite high level. Moreover, the knowledge of some interviewees concerning waste separation was correct only to some extent.

Very similar results concerning the levels of knowledge and separating waste skills were prior found in the research of Patcharaporn Viriyaprasopchock (2000). This author studied the affects from the waste separation campaign in Chiang Rai Municipality and found that people have knowledge and satisfaction with the very idea of separating waste in the middle level, however, their actual behavior concerning immediate separation of waste has low level. The level of awareness and knowledge on waste separating has very little relation with waste-separating.

The factors contributing to direct participation in waste management include the following: community cooperation in solving this the problem; more active campaigning to raise public awareness; campaigning about using less plastic in particular. Regarding plastic, it is often emphasized that this material is not directly dangerous to the humans but it is the direct cause for many environmental problems. In quite many cases leading by example 


\section{FACTORS AFFECTING LOCAL AUTHORITIES WASTE}

proved to be quite a successful tool in waste management. It is in particular applied in the following contexts:

(1) Demonstrating more interests in the products with longer durability or longer use life;

(2) Minimizing the volume of unnecessary waste components such as paper and plastic cover and packaging;

(3) More active promotion of recycling, especially in the cases of bottles, metal cans, paper, and plastic. It must be emphasized that such recycling does not only help the environment but it also reduces spending for households;

(4) Introducing pollution taxes, especially for productions that use packaging from the first-source materials, not recycled ones.

In terms of public awareness and waste management of interest is also a similar study carried out by Kingkarn Boonma (2004). This author studied the community experience in waste management on the example of new houses at the premises of a university in the Suthep sub-district, Mueang district, Chiang Rai province. And as it was pointed out in the mentioned study, for raising the level of public participation in waste management it is important that every person is involved and every person must be aware that he/she is also a waste generator. All members of a local community should be well aware of the potential public health effects as well as effects on the environment quality. This stronger public consciousness, in its turn, would increase the desire to raise the related skills and participate more actively in solving waste problems. This work with public awareness must be systemic and ongoing, and it must also cover all age groups.

\section{Suggestions}

From our study on the factors affecting participation in waste management at the community level we have come up with the following suggestions:

- There should be more focus on stronger cooperation in all aspects of waste management. These aspects include, inter alia, direct participation, public relation, trainings in waste management etc. Field work with people residing in the community must include and engage the representatives of the public sector, government official, private sector, community development organization and media;

- Public relation and awareness campaigns on waste management should be continuous, not occasional. However, the use of media source must vary depending on a target group so that to encourage and motivate all members of the community to cooperate in waste management and take it more seriously;

- Government agencies should demonstrate more support to people's engagement and interest in waste management. It would be also wise if a local government could found a separate department for consulting and monitoring over waste management processes at the community level. Local people must know what are the incentives for them from participation in waste management;

- Public direct participation should not mean only showing own opinion on the issue. It must, first of all, mean joint solution of the waste management problem via thorough planning, wider and more active campaigning, media promotion, discussing new suggestions on waste management, regular and timely reporting of the results to the members of the community etc. Performance evaluation must become a continuous process. 


\section{Acknowledgement}

The author would like to thank the Research and Development Institute, Suan Sunandha Rajabhat University, Bangkok, Thailand for financial support.

\section{References}

Boonma, K. (2004). Strength of the community in waste management in new house behind University. Suthep subdistrict Mueang district Chiang Mai province: Chiang Mai University.

Department of Environmental Quality (2004). Volunteer Resource and Environmental Volunteer Handbook, Vol. 1., Bangkok: Department of Environmental Quality, Ministry of Natural Resources and Environment.

Department of Environmental Quality (2003). Recycle garbage Bank Guild. Bangkok: Department of Environmental Quality, Ministry of Natural Resources and Environment.

Department of Environmental Quality (2006). Recycle garbage Bank Guild. Bangkok: Department of Environmental Quality, Ministry of Natural Resources and Environment.

Kotler, P. (2000). Marketing Management. 10th edition, United States of America: Prentice Hall International.

Narong Lao A-Long Korn. (2004). Development of a waste bank project and waste material in Ban Sum Nuk Ta Kro School Theparak sub-district Naknorrachsima province. Independence Study. M.Sc. Mahasarakham: Mahasarakham University.

Viriprasopchock, P. (2000). The impact of waste separation campaign in Mueang Municipality Chiang Rai. M.Sc. study (Human Resource Management). Chiang Mai: Chiang Mai University.

Paper submitted

Paper accepted for publishing

Paper published online
14 January 2018

18 March 2018

15 June 2018 